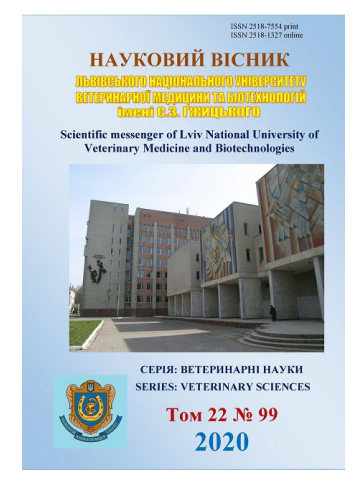

\author{
Науковий вісник Аьвівського національного університету \\ ветеринарної медицини та біотехнологій імені С.3. Гжицького. \\ Серія: Ветеринарні науки \\ Scientific Messenger of Lviv National University \\ of Veterinary Medicine and Biotechnologies. \\ Series: Veterinary sciences
}

UDC $340.66: 343.58: 636.09$

\title{
The procedure for forensic veterinary determination of the severity of harm caused to the health of the animal
}

\author{
I. V. Yatsenko, O. I. Parilovskyi, V. M. Zhylina \\ Kharkiv State Zooveterinary Academy, Kharkiv, Ukraine
}

Article info

Received 17.09.2020

Received in revised form 19.10.2020

Accepted 20.10.2020

Kharkiv State Zooveterinary Academy, Kharkiv, Ukraine Academic Str.1, Malaya Danilovka, Dergachi district, Kharkov region, 62341, Ukraine.

Tel.: +38-067-186-06-65

E-mail: yacenko-1971@ukr.net
Yatsenko, I. V., Parilovskyi, O. I., \& Zhylina, V. M. (2020). The procedure for forensic veterinary determination of the severity of harm caused to the health of the animal. Scientific Messenger of Lviv National University of Veterinary Medicine and Biotechnologies. Series: Veterinary sciences, 22(99), 182-192. doi: $10.32718 /$ nvlvet9928

The paper formulates the procedure for forensic veterinary determination of the severity of damage to animal health. According to the severity of injuries to animals, it is necessary to distinguish between injuries of three degrees: mild, moderate and severe. Forensic veterinary examination to determine the severity of injuries is carried out by a forensic veterinary expert through a veterinary examination of the injured (subject) animal. During the examination of the subject animal, the forensic veterinary expert establishes data about the animal according to the animal's passport or other document that replaces it (animal's nickname, individual number, species, sex, age, breed, etc.). If there are no documents for the animal, they are limited to information about the animal received from its owner or guardian; establishes the anamnestic data of the examined animal according to the explanations of the owner of the animal or its guardian; finds out the circumstances of the injury to the investigator, coroner, owner or guardian of the animal; clarifies complaints from the owner about the state of health of the animal; gets acquainted with the case materials provided by the law enforcement agency; examines other available veterinary documents, if necessary, finds out other information. The forensic veterinary expert, estimating the statute of limitations for violation of the anatomical integrity of tissues and organs and their functions, proceeds from their usual duration. Defects in veterinary care should not be taken into account when assessing the severity of injuries. In such cases, the forensic veterinary expert is obliged to indicate the nature of the causal relationship between the injury and such consequences. Damage to diseased tissues and organs of an animal can be considered as severe as damage to these organs and tissues in clinically healthy animals, if there is a direct causal link between the damage and the adverse effect. If during the examination of the subject animal the expert finds different origins of bodily injuries, he establishes what weapon of injury could have been inflicted on each of them. If the injuries are of different ages, indicate the frequency, non-simultaneity and sequence of their application, indicate the time of infliction of each of the injuries, determine the severity of each of them. In cases of death of an animal in the presence of bodily injuries, the forensic veterinary expert, along with resolving other issues, establishes the presence or absence of a causal link between the injury and the death of the animal. In cases where there is a causal link between injury and death, they can be considered fatal. All the information obtained is reflected in the expert's report or in the report of the expert study. The results in the expert's opinion should be the result of the analysis of objective information established during the forensic veterinary examination of the subject. They must be detailed and scientifically sound.

Key words: forensic veterinary examination, sub-expert animal, procedure for forensic veterinary determination of the severity of damage caused to animal health.

\section{Порядок судово-ветеринарного встановлення ступеня тяжкості шкоди, заподіяної здоров'ю тварини}

\author{
I. В. Яценко, О. І. Париловський, В. М. Жиліна
}

Харківська державна зооветеринарна академія, м. Харків, Україна 
В роботі сформульовано порядок судово-ветеринарного встановлення ступеня тяжкості шкоди, заподіяної здоров ю тварини. За ступенем тяжкості тілесних ушкоджень тварин необхідно розрізняти тілесні ушкодження трьох ступенів: легке, середньої тяжкості та тяжке. Судово-ветеринарна експертиза з метою встановлення ступеня тяжкості тілесних ушкоджень проводиться судово-ветеринарним експертом иляхом ветеринарного обстеження потерпілої (підекспертної) тварини. Під час дослідження підекспертної тварини судово-ветеринарний експерт встановлює дані про тварину за паспортом тварини чи іншим документом, щуо його замінює (кличку тварини, індивідуальний номер, вид, стать, вік, породу тощьо). Якщзо документи на тварину відсутні, то обмежуються інформачією про тварину, отриману від ї̈ власника чи опікуна; встановлює анамнестичні дані обстежуваної тварини за поясненнями власника тварини чи ї̈ опікуна; з ясовує обставини заподіяння ушкоджень у слідчого, дізнавача, у власника чи опікуна тварини; з'ясовує скарги від власника щодо стану здоров'я тварини; ознайомлюється з матеріалами справи, наданими правоохоронним органом; досліджує інші наявні ветеринарні документи, за потреби з'ясовує інші відомості. Судово-ветеринарний експерт, оцінюючи терміни давності порушення анатомічної цүілості тканини і органів та їх функцій, виходить із звичайної їх тривалості, навіть у тих випадках, коли тварина не була обстежена фахівцем ветеринарної медицини раніше, до проведення експертизитермінів. Дефекти надання ветеринарної допомоги не повинні враховуватися під час оиінки ступеня тяжкості тілесних ушкоджень. В таких випадках судово-ветеринарний експерт зобов'язаний вказувати характер причиннонаслідкових зв'язків між ушкодженням і такими наслідками. Уикодження хворобливо змінених тканин $і$ органів тварини може бути розцінене за ступенем тяжкості як таке ж ушкодження цих органів і тканин у клінічно здорових тварин, якщо між циим ушкодженням і несприятливим наслідком є прямий причинний зв'язок. Якщо під час обстеження підекспертної тварини експерт виявляє різне походження тілесних ушкоджень, він встановлює, яким знаряддям травми могло бути заподіяне кожне з них. Якще ушкодження мають різну давність, позначають неоднократність, неодночасність і послідовність їх нанесення, вказуються строки спричинення кожного з ушкоджень, встановлюється ступінь тяжкості кожного із них. У випадках смерті тварини за наявності тілесних ушкоджень судово-ветеринарний експерт поряд з вирішенням інших питань встановлює наявність чи відсутність причинного зв'язку між ушкодженням і смертю тварини. У випадках, коли між ушкодженням і смертю причинний зв'язок існує, то вони можуть бути оцінені як летальні. Всі отримані відомості відображаються у висновку експерта або у висновку експертного дослідження. Підсумки у висновку експерта повинні бути результатом аналізу об 'єктивних відомостей, щзо встановлені під час проведення судово-ветеринарної експертизи підекспертної тварини. Вони мають бути детальними і науково обтрунтованими.

Ключові слова: судово-ветеринарна експертиза, підекспертна тварина, порядок судово-ветеринарного встановлення ступеня тяжкості шкоди, заподіяної здоров'ю тварини.

\section{Вступ}

Встановлення ступеня тяжкості шкоди, заподіяної здоров'ю тварини - одне із питань, що ставиться на вирішення судово-ветеринарному експерту в постанові слідчого чи дізнавача або в ухвалі слідчого судді на стадії досудового розслідування правопорушень, пов'язаних із жорстоким поводженням 3 тваринами (Holovko, 2010; Grugan, 2019), порушенням умов та режиму їх утримання і експлуатації (Heyerhoff et al., 2014; Tosswill et al., 2018), а також транспортування (Hoffman et al., 2012; Riley et al., 2016; Padalino et al., 2015), браконьєрством (Higdon et al., 2008; Caudell et al., 2013; Li et al., 2015; Byrne et al., 2015), дресируванням та поводженням з тваринами, що використовуються у видовищних заходах, спорті та для організації дозвілля (Munoz et al., 2019; Bertuglia et al., 2020), ветеринарним обслуговуванням (McEwen, 2012), постановкою на тваринах експериментів 3 порушенням вимог законодавства (Weber et al., 2017), виловом та тимчасовою ізоляцією домашніх тварин (Proulx et al., 2020), примушуванням тварин до виконання дій, що їх травмують (Rowan et al., 1993; Alleyne et al., 2019), сексуальним насиллям над тваринами (Ascione et al., 2007), дорожньо-транспортними пригодами за участю тварин (Bruinderink et al., 1996; Langley et al., 2006; Conroy et al., 2019), вогнепальними травмами (Franckenberg et al., 2015; Panasiuk-Flak et al., 2020) тощо.

Визначення ступеня тяжкості тілесних ушкоджень тварин можливе виключно за допомогою судововетеринарної експертизи (Cooper et al., 1998; Mills, 2013; de Siqueira et al., 2016; Yatsenko \& Parylovskyi, 2020).

Саме судово-ветеринарний експерт вирішує питання щодо характеру травм, їх локалізації, встанов- лює механізм спричинення шкоди здоров'ю тварини за конкретних обставин і вказує на можливе знаряддя травмування (Yatsenko et al., 2019). Відповіді на ці та інші споріднені питання $є$ основою висновка експерта, який має важливе доказове значення у кримінальному і адміністративному судочинстві (Benetato et al., 2011).

Проте правильна і об'єктивна експертна оцінка тяжкості шкоди, заподіяної здоров'ю тварини, є однією із складних і не досліджених проблем у ветеринарній медицині взагалі та судово-ветеринарній експертизі, зокрема.

Нами вже проаналізовані судово-експертні випадки дослідження трупів тварин з ознаками насильницької смерті від жорстокого поводження в Україні (Yatsenko et al., 2018; 2020), запропонована авторська редакція дефініції “жорстоке поводження 3 тваринами” (Yatsenko \& Parylovskyi, 2020), розроблені та звернені до використання в практиці судововетеринарної експертизи ознаки шкоди, заподіяної здоров'ю, небезпечної для життя тварини (Yatsenko et al., 2019), започатковане вчення про каліцтво тварин (Yatsenko et al., 2019). Проте, підвищення ефективності судово-ветеринарної експертизи можливе шляхом правової регламентації процедури іiі проведення на практиці.

Таким чином, зважаючи на те, що нині в Україні відсутня юридично затверджена й обов'язкова для виконання усіма суб'єктами експертної діяльності методика визначення ступеня тяжкості шкоди, заподіяної здоров'ю тварини, а також в спеціальній науковій літературі не описана процедура організації й проведення такого виду експертизи, то підняте питання $\epsilon$ актуальним для судово-ветеринарної експертизи і юриспруденції як з теоретичної, так і з практичної точки зору, а, отже, потребує їі розроблення, 
обгрунтування, систематизації етапів і впровадження в експертну практику.

\section{Матеріал і методи досліджень}

3 урахуванням специфіки теми, мети і завдань дослідження в роботі використано наукові методи, зокрема: формально-юридичний, діалектичний, порівняльно-правовий, системного аналізу, моделювання, аналіз висновків експертів за результатами проведення судово-ветеринарної експертизи.

Емпіричну базу дослідження становить аналіз висновків експертів за результатами судововетеринарних експертиз щодо жорстокого поводження 3 тваринами, проведених в Бюро судововетеринарних досліджень Харківської державної зооветеринарної академії протягом 2010-2020 років, а також в лабораторії криміналістичних досліджень Національного наукового центру "Харківський науково-дослідний інститут судових експертиз ім. М. С. Бокаріуса" Міністерства юстиції України.

Робота $€$ частиною наукової теми «Теоретикоправові засади судово-ветеринарної експертизи тварин з ознаками жорстокого поводження 3 ними», яка виконується на базі кафедри ветеринарно-санітарної експертизи та судової ветеринарної медицини Харківської державної зооветеринарної академії. Державний реєстраційний номер - $0118 \mathrm{U} 004677$.

\section{Результати та їх обговорення}

Визначення ступеня тяжкості шкоди, заподіяної здоров'ю тварини, проводиться для оцінки ушкоджень, виявлених під час судово-ветеринарної експертизи живої тварини, трупа чи його частин, а також проведенні судово-ветеринарної експертизи за матеріалами справи.

Шкода, заподіяна здоров'ю тварини полягає в тимчасовому або стійкому порушенні функцій органів i (або) систем організму, внаслідок ушкодження, захворювання, патологічного стану, який зумовив тимчасову чи стійку втрату роботоздатності тварини.

Тілесні ушкодження у тварини - це порушення анатомічної цілісності тканин, органів, систем організму, частин тіла та порушення їх функцій, що виникли внаслідок дії одного чи кількох екзогенних травмуючих чинників.

Загальні вимоги, що ставляться в Україні до складання висновку експерта, в т.ч. за результатами визначення ступеня тяжкості шкоди, заподіяної здоров'ю тварини, а також правовий статус експерта, в т.ч. й судово-ветеринарного, регламентовані Кримінальним процесуальним кодексом України (Kryminalnyi protsesualnyi kodeks Ukrainy, № 4651-VI), Законом України "Про судову експертизу" (Pro sudovu ekspertyzu: Zakon Ukrainy. Vidomosti Verkhovnoi Rady Ukrainy, 1994), “Інструкцією про призначення та проведення судових експертиз та експертних досліджень" (Instruktsiia pro pryznachennia i provedennia sudovykh ekspertyz, 1998).
Проведення судово-ветеринарної експертизи з визначення ступеня тяжкості шкоди, заподіяної здоров'ю тварини здійснюється на основі юридичної та фактичної підстав. Юридичною підставою $є$ постанова слідчого або дізнавача, або ухвала суду, а фактичною - фактичні дані (юридичний факт), котрі можуть бути досліджені експертом і за результатами дослідження яких може бути сформульовано висновок експерта.

Особа, яка призначила судово-ветеринарну експертизу надає експерту: документ про іiї призначення, в якому зазначаються вид і кличка підекспертної тварини, кому вона належить та інші відомості про тварину, матеріали провадження (протоколи огляду чи інструментальних досліджень тварини 3 додатками, протокол огляду місця події, виписка з історії хвороби тощо), а також на дослідження доставляється підекспертна тварина.

Якщо підекспертна тварина не може бути доставлена експертові, експертиза може проводитись 3 використанням фотознімків цієї тварини з детальним їх описанням, доданими до провадження, якщо це не суперечить "Методичним рекомендаціям з визначення ступеня тяжкості тілесних ушкоджень тварин”.

Для виконання додаткової або повторної судововетеринарної експертизи для встановлення ступеня шкоди, заподіяної здоров'ю тварини, експертові надаються висновки первинної експертизи, а також додаткові матеріали, що стосуються предмета експертизи, які були отримані після оформлення висновку первинної експертизи, що узгоджується 3 n.3.6 "ІІнструкції про призначенні і проведення судових експертиз і експертних досліджень”.

Якщо проведення комплексної судововетеринарної експертизи доручено експертам кількох експертних установ, у документі про призначення експертизи зазначається, яка 3 них здійснює організацію проведення експертизи, тобто є провідною установою. Об'єкти дослідження і матеріали провадження направляються в провідну експертну установу, , що узгоджується 3 n.3.7 "Інструкції про призначенні і проведення судових експертиз і експертних досліджень”.

Відповідно до $n .3 .9$ “ІІнструкції про призначення та проведення судових експертиз та експертних досліджень", якщо необхідно провести судово-ветеринарну експертизу або виконати експертне дослідження на місці події або провести огляд підекспертної тварини за іiі місцезнаходженням, особа, яка призначила експертизу, має забезпечити прибуття експерта, безперешкодний доступ до підекспертної тварини, а також належні умови для проведення експертизи (дослідження тварини в клініці ветеринарної медицини будякої форми власності), а за потреби викликати учасників процесу або інших осіб. Якщо особи, що викликалися не з'явилися без поважних причин, огляд підекспертної тварини проводиться без їх участі, про що зазначається у висновку експерта.

Керівник експертної установи чи його заступник доручає проведення експертизи відповідному структурному підрозділу експертної установи, що узгоджу- 
ється 3 n.4.1 "Інструкції про призначення і проведення судових експертиз і експертних досліджень”.

Відповідно до $n .4 .5$ цієї ж Інструкції, організовуючи проведення комплексної експертизи, керівник експертної установи доручає іiї проведення відповідним підрозділам експертної установи, зазначаючи, який з них $є$ провідним. Керівник провідного підрозділу за погодженням з керівниками інших підрозділів утворює експертну комісію і призначає ії голову.

Якщо клопотання експерта про надання йому додаткових матеріалів не виконане протягом 45 календарних днів, то він письмово повідомляє особу, яка призначила експертизу про неможливість надання висновку експерта.

Судово-ветеринарна експертиза 3 метою встановлення ступеня тяжкості шкоди, заподіяної здоров'ю тварини проводиться судово-ветеринарним експертом шляхом ветеринарного обстеження підекспертної живої тварини, трупа тварини чи його частин, а також проведенні експертизи за матеріалами справи. У разі відсутності такого експерта, судово-ветеринарна експертиза може бути проведена лікарем ветеринарної медицини, який має освітній рівень спеціаліста або магістра і є компетентним в цій сфері ветеринарної діяльності.

Компетентність лікаря ветеринарної медицини у сфері судово-ветеринарної експертизи підтверджується наявним у нього науковим ступенем з відповідної спеціальності, вченим званням за відповідною кафедрою, наявними науковими публікаціями, участю в науково-практичних конференціях чи семінарах 3 напряму судово-ветеринарної експертизи, досвідом практичної роботи щодо проведення судововетеринарної експертизи (експертних досліджень).

Розпочинається судово-ветеринарна експертиза 3 визначення ступеня тяжкості шкоди, заподіяної здоров'ю тварини, з того, що експерт за ії паспортом чи іншим документом, що його замінює встановлює дані про тварину: кличку тварини, індивідуальний номер, вид, стать, вік, породу тощо. Якщо документи на тварину відсутні, то обмежуються інформацією про тварину, отриману від іiі власника чи опікуна; встановлює анамнестичні дані підекспертної тварини за поясненнями власника тварини чи іiі опікуна; з'ясовує обставини заподіяння ушкоджень у слідчого, дізнавача, у власника чи опікуна тварини; з'ясовує скарги від власника щодо стану здоров'я тварини; ознайомлюється 3 матеріалами справи, наданими правоохоронним органом для дослідження; досліджує інші наявні ветеринарні документи, за потреби знайомиться 3 іншими відомостями. Всі отримані відомості відображаються у висновку експерта або в експертному дослідженні.

Якщо для об’єктивного проведення судововетеринарної експертизи чи експертного дослідження експерту не надані необхідні ветеринарні чи інші документи, які мають значення для встановлення шкоди, заподіяної здоров'ю тварини, експерт заявляє клопотання про надання відповідних документів протягом строку, передбаченого "Інструкцією про призначення та проведення судових експертиз в Україні"
(Instruktsiia pro pryznachennia i provedennia sudovykh ekspertyz, 1998).

Фахівці ветеринарної медицини закладів ветеринарної медицини будь-якої форми власності можуть залучатися до надання допомоги судововетеринарному експерту під час проведення ним експертизи чи експертного дослідження для консультацій, клінічного обстеження, здійсненні лабораторних досліджень тощо.

Під час проведення судово-ветеринарної експертизи чи експертного дослідження експерт повинен посилатися на оригінали ветеринарних чи інших документів (історію хвороби, карту амбулаторної хворої тварини тощо чи виписку з них), які пов'язані з предметом експертизи чи експертного дослідження. У виняткових випадках можна використати засвідчені належним чином копії ветеринарних документів 3 наявністю підпису лікаря ветеринарної медицини і печаткою закладу ветеринарної медицини, де лікували тварину, виготовлені згідно з оригіналами, якщо в останніх вичерпно відображені відомості про характер ушкоджень, їх локалізацію, клінічний перебіг та інші необхідні відомості, що мають суттєве значення для експертизи.

За певних обставин судово-ветеринарний експерт може використовувати відомості досліджень, що проводяться чи проводилися із залученням вузькопрофільних фахівців ветеринарної медицини, котрі спеціалізуються в певній сфері ветеринарної медицини кардіології, травматології, хірургії, репродуктології, ендокринології, неврології тощо, не обстежуючи потерпілої тварини особисто. У цьому випадку такі відомості досліджень мають бути викладені письмово у вигляді довідки, виписки з історії хвороби чи картки амбулаторного хворого, засвідчені особистими підписами цих фахівців та засвідчені печаткою установи в якій вони проводили лікування чи клініколабораторні дослідження підекспертної тварини. У цих випадках у висновку експерта чи висновку експертного дослідження зазначається: де, коли і ким досліджувалася підекспертна тварина; які об'єктивні дані при цьому встановлені; яких висновків дійшов фахівець ветеринарної медицини.

Якщо виникла необхідність в спеціальному судово-ветеринарному обстеженні живої підекспертної тварини, за участю лікарів ветеринарної медицини, проводиться комісійна судово-ветеринарна експертиза в закладі ветеринарної медицини будь-якої форми власності, де $\epsilon$ необхідні умови для іiі проведення.

Судово-ветеринарна експертиза проводиться виключно комісією експертів у складі не менше двох осіб у випадку неналежного надання тварині ветеринарної допомоги, що виявилася в порушенні анатомічної цілісності тканин, органів чи окремих ділянок тіла та порушенні їх функцій, в результаті чого виникли негативні наслідки у вигляді розладу здоров'я чи смерті. Комісія експертів може розглядати таке порушення як шкоду, заподіяну здоров'ю тварини, у вигляді ушкодження і визначити ступінь їі тяжкості за схемою: тварина - травма - втрата органа чи втрата органом його функцій за відсутності захворювань, 
індивідуальних особливостей організму тварини, здатних самостійно привести до втрати органа чи втрати органом своїх специфічних функцій.

Підсумки складаються експертом або комісією експертів на основі отриманих результатів дослідження.

Ступінь тяжкості шкоди, заподіяної здоров'ю тварини, визначається за судово-ветеринарними критері- ями, котрі $\epsilon$ ветеринарною характеристикою ознак тяжкості ушкоджень. За ступенем тяжкості необхідно розрізняти шкоду, заподіяну здоров'ю тварини, трьох ступенів: тяжку, середньої тяжкості та легкого ступеня (рис. 1).

Алгоритм оцінки ступеня тяжкості шкоди, заподіяної здоров’ю тварини

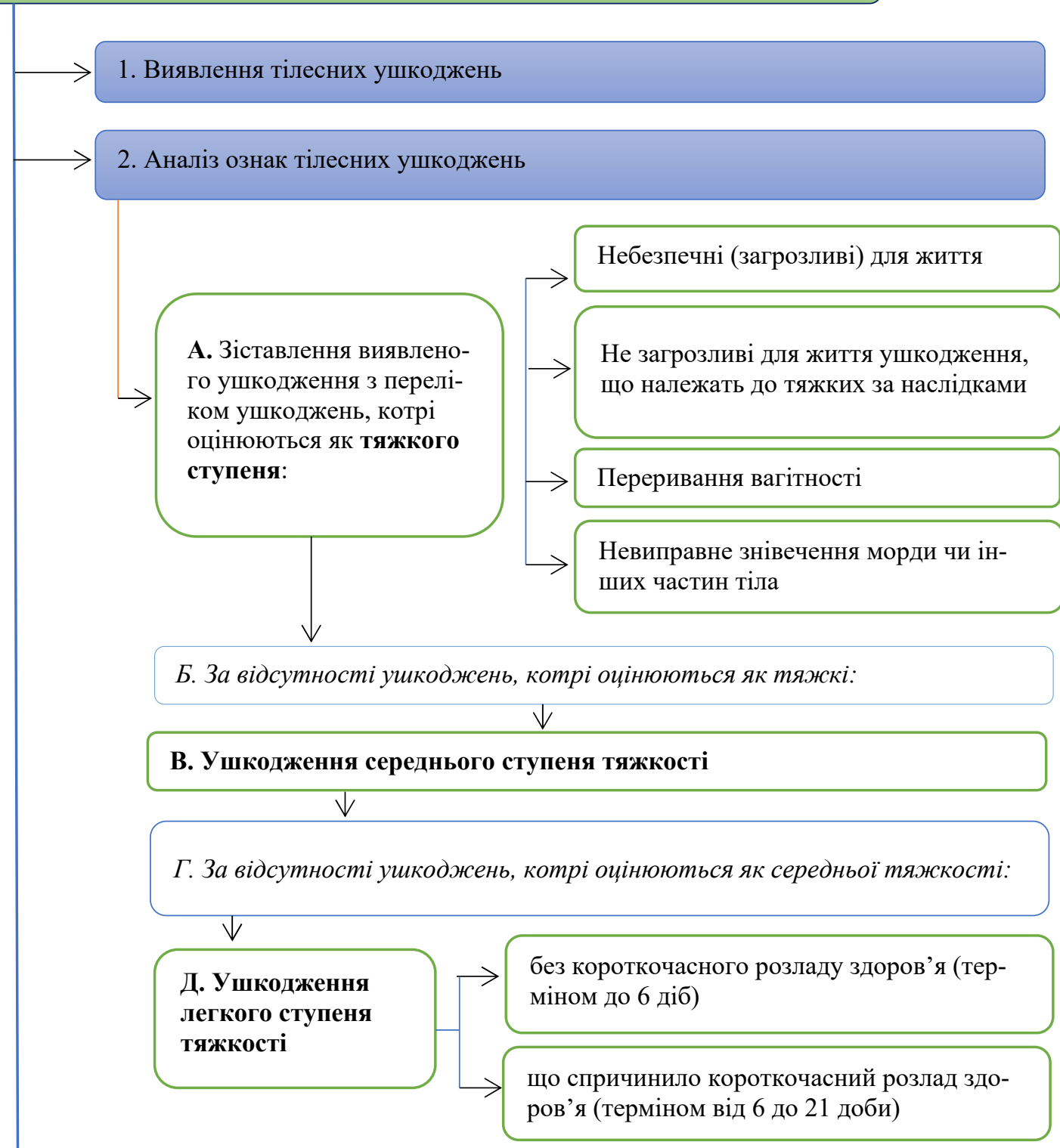

\section{3. Оцінка ступеня тяжкості шкоди, заподіяної здоров’ю тварини}

Рис. 1. Алгоритм оцінки ступеня тяжкості шкоди, заподіяної здоров’ю тварини

Кваліфікуючі ознаки тяжкості шкоди, заподіяної здоров'ю тварини, визначається виключно на основі об'єктивних даних, зазначених у ветеринарних документах або отриманих під час безпосереднього обстеження підекспертної тварини судововетеринарним експертом. Якщо такі об'єктивні дані на момент проведення експертизи відсутні, то експерт зазначає цю обставину у своєму висновку.

Виникнення загрозливого для життя тварини стану має бути пов'язане безпосередньо із заподіянням шкоди здоров'ю, небезпечної для життя тварини, причому цей зв'язок має бути не випадковим, а закономірним. 
Тривалість порушення функції систем організму чи окремих органів, а також термін втрати твариною роботоздатності встановлюється в добах, виходячи 3 об'єктивних ветеринарних даних, оскільки термін лікування може не збігатися 3 тривалістю функціональних обмежень органів тварини.

Проведене лікування тварини не виключає обмеження функцій органів, систем організму у підекспертної тварини в період після спричинення ушкодження.

У висновку експерта з приводу проведення судово-ветеринарної експертизи для визначення ступеня тяжкості шкоди, заподіяної здоров’ю тварини повинні бути відображені такі питання:

1) До якого виду і класу відноситься тварина, яку досліджено, згідно зоологічної систематики?

2) Які фізіологічні особливості потерпілої тварини?

3) Яким є характер ушкоджень з ветеринарної точки зору (садно, синець, рана, перелом кістки тощо) та яка їх локалізація?

4) Який механізм виникнення тілесних ушкоджень у тварини?

5) Яка черговість і послідовність заподіяння ушкоджень, виявлених у тварини?

6) Чи могли ушкодження виникнути без постороннього втручання?

7) Чи можна за характером ушкодження встановити, яким знаряддям травми вони спричинені?

8) Яка давність виникнення тілесних ушкоджень у тварини?

9) Якого ступеня тяжкості кожне з ушкоджень, виявлених в тілі тварини?

10) Чи є ушкодження, завдані тварині, небезпечними для життя в момент їх заподіяння, а якщо так, то чим зумовлена їх небезпечність?

11) До яких наслідків для здоров'я тварини призвело кожне із спричинених ушкоджень, i якими $є$ наслідки в їх сукупності?

12) Чи були в наданні ветеринарної допомоги підекспертній тварині недоліки, що стали причиною спричинення їй ушкоджень, а якщо так, то який ступінь тяжкості цих ушкоджень?

13) Чи є втрата загальної і спеціальної роботоздатності потерпілої тварини стійкою, і якщо є, то який їх термін?

14) Чи існує причинно-наслідковий зв'язок між спричиненими тварині тілесними ушкодженнями за встановлених обставин і розладом іiї здоров'я?

15) Чи призвели до каліцтва тварини спричинені їй ушкодження за встановлених обставин як кожне окремо, так і в сукупності?

16) Чи вплинуло і як саме наявне каліцтво у тварини на термін стійкої втрати загальної роботоздатності у зв'язку з одержаною цією твариною травми?

17) Чи існує причинний зв'язок між спричиненим тварині ушкодженням за встановлених обставин і перериванням вагітності?

18) Механізм ушкодження морди або інших частин тіла тварини, і чи є таке ушкодження невиправ- ним, а якщо так, то яким є ступінь тяжкості заподіяного ушкодження?

19) Чи є ушкодження морди або інших частин тіла тварини виправним, а якщо так, то яким є ступінь тяжкості заподіяного ушкодження?

20) Чи є на тілі підекспертної тварини сліди, які вказують на заподіяння їй болю, а якщо так, то яким $\epsilon$ механізм їх утворення та давність виникнення?

21) Чи вплинули дії, пов'язані з тривалим позбавленням підекспертної тварини тепла, корму, пиття, утримання ii в умовах, шкідливих для здоров'я за умов, зазначених в постанові слідчого чи ухвалі суду, на стан здоров'я підекспертної тварини, і як саме?

22) Чи спричинили виявлені у підекспертної тварини тілесні ушкодження фізичний біль і страждання?

Перелік запропонованих питань не є вичерпним, він може змінюватися в залежності від обставин події, за якої тварині спричинена шкода здоров'ю.

Оцінюючи терміни давності порушення цілісності тканини, органів, частини тіла та їх функцій, судововетеринарний експерт виходить із звичайної їх тривалості, навіть тоді, коли власник підекспертної тварини не звертався за ветеринарною допомогою до моменту проведення експертизи. Якщо тривалість порушення, що зазначена в наявних ветеринарних документах, не відповідає характеру ушкодження і не підтверджується об'єктивними даними, то судово-ветеринарний експерт вказує на цю обставину і встановлює ступінь тяжкості кожного з ушкоджень, виходячи з виявлених ним особисто об'єктивних даних.

Оцінка тяжкості шкоди, заподіяної здоров'ю тварини за аналогією наслідків у більшості потерпілих тварин, не допускається.

В основі висновку судово-ветеринарного експерта має лежати принцип “так було” чи “так $\epsilon$ ”, а не “так буває”, адже завданням судово-ветеринарного експерта $є$ надати експертну оцінку об'єктивно виявленого, а неможливого, усередненого ушкодження.

Під час визначення ступеня тяжкості шкоди, заподіяної здоров'ю тварини, не береться до уваги запобігання смертельного наслідку травми, обумовленого наданням ветеринарної допомоги.

Заподіянням шкоди здоров'ю тварини є погіршення стану здоров'я підекспертної тварини, обумовлене дефектом надання ветеринарної допомоги.

Під час проведення судово-ветеринарної експертизи живої підексперної тварини, яка має захворювання, що розвилося до спричинення ушкодження 3 повністю або частково раніше втраченою (до травми) функцією, враховується лише шкода, заподіяна здоров'ю тварини, спричинена травмою та зв'язана $з$ нею причинно-наслідковим зв'язком.

Загострення хронічних захворювань в період після заподіяння тварині шкоди здоров'ю, а також інші іiі наслідки, що обумовлені не власне характером цієї шкоди, а випадковими обставинами (наприклад, тимпанією, інвагінацією петель кишечника, копростазом, тепловим або сонячним ударами тощо), індивідуальними особливостями організму (наприклад, анемією), дефектами надання ветеринарної допомоги тощо не повинні враховуватися під час оцінки ступеня тяжко- 
сті шкоди, заподіяної здоров'ю тварини. За таких обставин судово-ветеринарний експерт зобов'язаний вказувати характер причинно-наслідкових зв'язків між шкодою, заподіяною здоров'ю тварини і такими наслідками.

Ушкодження хворобливо змінених тканин і органів тварини оцінюють за ступенем тяжкості як ушкодження цих же органів і тканин у клінічно здорових тварин, якщо між цим ушкодженням і несприятливим наслідком $є$ прямий причинно-наслідковий зв’язок.

Якщо під час обстеження підекспертної тварини експерт виявляє ушкодження різного походження, він встановлює, чим могло бути заподіяне кожне 3 них. Якщо у тварини виявлені ушкодження різної давності, то експерт має зазначити неоднократність і неодночасність їх нанесення, вказує строки спричинення кожного 3 ушкоджень, встановлює ступінь тяжкості кожного із них, послідовність нанесення.

Діагноз забиття м'яких тканин підекспертної тварини має бути поставлений виключно за об'єктивними клінічним дослідженнями. Цей діагноз не враховується для оцінки ступеня тяжкості шкоди, заподіяної здоров'ю тварини, якщо він встановлений за суб'єктивними даними i не підтверджується об'єктивними дослідженнями.

Підсумки у висновку експерта повинні бути детальним і науково обгрунтованим результатом аналізу фактичних даних, встановлених під час проведення судово-ветеринарної експертизи.

Складання “попередніх висновків” чи надання будь-якої попередньої інформації, що містять ймовірне твердження про ступінь тяжкості шкоди, заподіяної здоров’ю тварини, неприпустиме.

У разі виявлення ушкоджень різних за ступенем тяжкості експерт не повинен визначати цей ступінь “у сукупністі” ушкоджень за найбільш тяжким. В таких випадках кожне ушкодження має бути описане і оцінене окремо. Проте об'єднання однотипних за ступенем тяжкості ушкоджень можливе.

Ступінь тяжкості шкоди, заподіяної здоров'ю тварини за наявності кількох тілесних ушкоджень, котрі утворилися від багаторазових травмуючих впливів, в т.ч. під час надання ветеринарної допомоги, визначається окремо для кожного такого впливу.

У випадку, якщо кілька ушкоджень взаємно обтяжують одне одного, або за наявності ушкоджень різної давності, ступінь тяжкості шкоди, заподіяної здоров'ю тварині, проводиться окремо для кожного такого ушкодження.

У випадках встановлення за об'єктивними ветеринарними відомостями, що шкода, заподіяна здоров'ю тварини, була небезпечною для життя, або коли наслідки і завершення процесу протікання ушкодження, тобто його загоєння, що не було небезпечним для життя, не викликає сумнівів, судово-ветеринарний експерт визначає ступінь тяжкості шкоди, заподіяної здоров'ю тварини, не очікуючи його завершення (загоєння).

Виникнення загрозливих для життя станів тварини має перебувати у причинно-наслідковому зв'язку із заподіянням шкоди здоров'ю, небезпечної для іiі жит- тя, а також такий зв'язок не може носити випадкового характеру.

Побої тварини характеризуються заподіянням багаторазових ударів, тому не становлять особливого виду ушкоджень. Якщо після побоїв на тілі підекспертної тварини виявляються ушкодження, їх оцінюють за ступенем тяжкості, виходячи із ознак, описаних в методичних рекомендаціях. Якщо після побиття тварини на їі тілі не залишилися жодних слідів, судововетеринарний експерт відмічає скарги власника чи опікуна тварини за наявності таких, вказуючи, що об'єктивних ознак ушкоджень не виявлено, а тому і не встановлює ступеня тяжкості шкоди, заподіяної здоров'ю тварини.

У разі заподіяння тварині мук і мордування судово-ветеринарний експерт повинен встановити лише наявність, характер, локалізацію, кількість ушкоджень, одночасність чи різночасність їх утворення, особливості ушкоджуючих предметів, механізм їх дії, а також ступінь тяжкості тілесних ушкоджень.

У тварини з ознаками каліцтва на момент спричинення шкоди здоров'ю стійка втрата працездатності у зв'язку з ушкодженням визначається як у клінічно здорових тварин, незалежно від наявності каліцтва, за винятком тих випадків, коли каліцтво пов'язане із захворюванням або новим ушкодженням органів чи частини тіла, що були травмовані раніше.

Розмір стійкої втрати загальної роботоздатності таких тварин, через спричинене ушкодження, необхідно визначати 3 урахуванням об'єктивної стійкої втрати загальної роботоздатності від попереднього ушкодження.

Втрата загальної роботоздатності у молодняка тварин визначається виходячи із того, що ця втрата настане після досягнення твариною віку роботоздатності.

Судово-ветеринарний експерт діагностує ушкодження морди тварини чи інших частин іiі тіла як знівечення, встановлючи, чи є воно виправним або невиправним. Крім того, він визначає вид ушкодження, його особливості й механізм утворення. Ступінь тяжкості такого ушкодження визначається виходячи 3 встановлених у судово-ветеринарній експертизі критеріїв, викладених у методичних рекомендаціях. Не виправне знівечення частин тіла може бути оцінене як каліцтво тварини.

Судово-ветеринарний експерт, досліджуючи тварину, якій спричинена шкода здоров'ю, повинен завжди визначити ступінь іiі тяжкості. Ступінь тяжкості шкоди, заподіяної здоров'ю тварини не визначається у разі:

1) відсутності клінічних ознак чи недостатнього клініко-інструментального і лабораторного обстеження потерпілої тварини;

2) на момент судово-ветеринарного обстеження не завершилися процеси загоювання ушкодження, що не було небезпечним для життя;

3) відмови власника (опікуна) підекспертної тварини від додаткового обстеження чи додаткового клініко-інструментального дослідження, якщо це не дозволяє експерту достовірно оцінити характер ушко- 
дження, його клінічний перебіг, а також завершення його перебігу (загоєння).

4) відсутності ветеринарних документів, в тому числі достатніх результатів додаткових клінікоінструментальних i лабораторних досліджень, без яких не можна оцінити характер і ступінь тяжкості шкоди, заподіяної здоров'ю підексперної тварини;

5) в процесі судово-ветеринарного обстеження живої підекспертної тварини, дослідження матеріалів провадження i ветеринарних документів визначити ступінь тяжкості шкоди, заподіяної здоров'ю тварини не виявляється за можливе;

6) не надання підекспертної живої тварини експерту для судово-ветеринарного дослідження.

Якщо встановити ступінь тяжкості шкоди, заподіяної здоров'ю тварини, не виявляється за можливе, то судово-ветеринарний експерт у підсумках проведеної експертизи обгрунтовує причини з яких це зробити не можливо і зазначає, які додаткові дані необхідні йому для вирішення цього питання (ветеринарні документи, результати додаткових досліджень тощо), а також встановлює термін повторного чи додаткового дослідження. Це не звільняє експерта від вирішення інших питань, поставлених йому на вирішення в документі про призначення судово-ветеринарної експертизи.

Крім живих підекспертних тварин, об'єктом визначення ступеня шкоди, заподіяної здоров'ю тварини $\epsilon$ і трупи тварин. У випадках смерті тварини у якої реєструються тілесні ушкодження, судововетеринарний експерт, відповідаючи на питання, поставлені йому на вирішення в документі про призначення судово-ветеринарної експертизи, зобов'язаний встановити наявність чи відсутність причиннонаслідкового зв'язку між ушкодженням і смертю тварини.

Під час експертизи трупа тварини встановлюється лише морфологічна характеристика ушкоджень і відсутні відомості про стадії перебігу, терміну загоєння, можливих порушеннях функцій органів чи окремих ділянок тіла. В таких випадках експерт може лише передбачати наслідки перебігу ушкодження, що за певних обставин може виявитися недостатньо обгрунтованим для кваліфікації ступеня тяжкості шкоди, заподіяної здоров'ю тварини.

Якщо в ухвалі слідчого судді чи в постанові слідчого про призначення судово-ветеринарної експертизи є питання щодо ступеня тяжкості ушкодження, виявлених на трупі тварини, судово-ветеринарний експерт повинен зазначити, ознаки, якого ступеня тяжкості (тяжкого, середньої тяжкості чи легкого) спостерігаються.

Під час дослідження трупа тварини про заподіяну шкоду здоров'ю тварини тяжкого ступеня можна стверджувати, якщо між ушкодженням і смертю існує прямий причинно-наслідковий зв'язок і безпосередньо або через свої ускладнення призвело до смертельного результату; ушкодження має хоч оду з ознак небезпечного для життя, виявлену під час дослідження трупа тварини або зафіксоване у медичних документах; виявлені патоморфологічні ознаки втрати зору, слуху, кінцівки, продуктивності, репродуктивної здатності, або у ветеринарних документах зафіксовані відомості про об’єктивні ознаки втрати функції хоча б однієї з цих функцій.

Шкода, заподіяна здоров'ю тварини, що призвела до іiі смерті, буде середнього ступеня тяжкості, якщо на трупі тварини відсутні ознаки шкоди здоров'ю тяжкого ступеня, а смерть в посттравматичному періоді, в т.ч. і під час незавершеного лікування тварини, настала більш ніж за 21 добу після спричинення травми, або, якщо існують виявлені під час об'єктивного дослідження трупа чи у ветеринарних документах об'єктивні ознаки значної стійкої втрати роботоздатності тварини.

Шкода, заподіяна здоров'ю тварини, що призвела до іiі смерті, буде легкого ступеня тяжкості, якщо на трупі тварини відсутні ознаки тяжкої або середньої тяжкості шкоди здоров'ю, а смерть настала в посттравматичний період, в т.ч. під час незавершеного лікування тварини, в термін, що не перевищує 21 добу після спричинення ушкодження, або, якщо існують виявлені під час дослідження трупа чи у ветеринарних документах об'єктивні ознаки незначної стійкої втрати роботоздатності тварини.

Встановлюючи причинно-наслідковий зв'язок між ушкодженням, виявленим у тварини і смертю, судововетеринарний експерт не повинен оцінювати це ушкодження як безумовно чи умовно летальне. Якщо між ушкодженням і смертю тварини існує причиннонаслідковий зв'язок, ці ушкодження можуть бути ним оцінені як такі, що призвели до смерті.

В процесі проведення судово-ветеринарної експертизи підекспертної тварини експерт повинен вжити заходів для недопущення можливості спричинення їй додаткових ушкоджень під час маніпуляцій, а також спричинення болю тощо.

Якщо під час проведення судово-ветеринарної експертизи щодо встановлення шкоди, заподіяної здоров'ю тварини, труп тварини під час розтину буде пошкоджений, то у документі про призначення експертизи має бути дозвіл на його пошкодження. Якщо такий дозвіл відсутній, то на пошкодження трупа має бути отримана окрема письмова згода особи, яка призначила експертизу, що узгоджується 3 n.4.12 "ІІнструкції про призначенні і проведення судових експертиз і експертних досліджень”.

У разі пошкодження трупа тварини в процесі дослідження до висновку експерта вноситься про це відповідний запис. Пошкоджений під час дослідження труп тварини або його залишки, а також документальні матеріали провадження повертаються особі, яка призначила експертизу, що узгоджується 3 n.4.12 "Інструкції про призначенні і проведення судових експертиз і експертних досліджень”.

Висновок комісії експертів підписується експертами, які брали участь у сукупній оцінці результатів усіх досліджень і дійшли згоди. Якщо вони не прийшли до згоди між собою, складаються стільки висновків експертів, скільки виявилось точок зору або один, у якому вступна і дослідницька частини підписуються всіма експертами, а заключна - окремими 3 відповідними висновками або згідно з проведеними 
ними дослідженнями, що узгоджується 3 n.4.10 “ІІнструкції про призначенні і проведення судових експертиз і експертних досліджень".

Відповідно до $n .4 .13$ цієї ж Інструкції висновок експерта або повідомлення про неможливість надання висновку розглядається керівником або заступником керівника підрозділу та керівником експертної установи і скеровується особі, яка призначила експертизу.

Якщо під час ознайомлення 3 висновком експерта буде встановлено, що дослідження підекспертної тварини проведені 3 порушенням методики дослідження, керівник експертної установи може передоручити проведення судово-ветеринарної експертизи комісії експертів, до якої включається також експерт, який проводив попереднє дослідження, що узгоджується 3 n.4.13 “Інструкції про призначенні і проведення судових експертиз і експертних досліджень”.

Висновок експерта, в якому виявлені технічні помилки, повертається експерту для доопрацювання.

Висновок судово-ветеринарного експерта оформляється в кількості, визначеній “Інструкцією про призначенні і проведення судових експертиз і експертних досліджень" (Instruktsiia pro pryznachennia i provedennia sudovykh ekspertyz, 1998) та видається персонально особі або органу, що призначили судововетеринарну експертизу, чи за їх письмовою вказівкою надсилається поштою не пізніше терміну, визначеного чинним законодавством.

Видача висновку судово-ветеринарної експертизи на руки власнику чи опікуну підекспертної тварини, яка була обстежена, можлива лише за письмовим дозволом слідчого чи суду, який призначив судововетеринарну експертизу. Заміна висновку судововетеринарної експертизи іншими документами не дозволяється.

\section{Висновки}

Визначення ступеня тяжкості шкоди, заподіяної здоров'ю тварини, проводиться для оцінки ушкоджень, виявлених під час судово-ветеринарної експертизи живої тварини, трупа чи його фрагментів, а також проведенні судово-ветеринарної експертизи за матеріалами справи.

Алгоритм оцінки ступеня тяжкості шкоди, заподіяної здоров'ю тварини полягає у виявленні тілесних ушкоджень, аналізі та зіставленні виявлених ознак ушкодження 3 переліком ознак ушкоджень, котрі оцінюються як тяжкі, середньої тяжкості чи легкі за ступенем тяжкості та оцінці ступеня тяжкості шкоди, заподіяної здоров'ю тварини.

Якщо під час обстеження підекспертної тварини експерт виявляє різне походження тілесних ушкоджень, він встановлює, яким знаряддям травми могло бути заподіяне кожне з них. Якщо ушкодження мають різну давність, констатують неоднократність, неодночасність і послідовність їх нанесення, вказується термін спричинення кожного з ушкоджень, встановлюється ступінь тяжкості кожного із них.

У випадках смерті тварини від ушкоджень, судово-ветеринарний експерт поряд 3 вирішенням інших питань встановлює наявність чи відсутність причинно-наслідкового зв'язку між ушкодженням і смертю тварини. Якщо такий зв'язок існує, то вони можуть бути оцінені як летальні тяжкого, середньої тяжкості чи легкого ступенів тяжкості.

Сформульовані питання, які можуть бути поставлені на вирішення судово-ветеринарному експерту під час визначення ступеня тяжкості шкоди, заподіяної здоров'ю потерпілої тварини, базуються на принципах формальної логіки, діалектики, системного аналізу, моделювання та вплинуть на ефективність призначення та проведення судово-ветеринарної експертизи, в т.ч. за жорстокого поводження.

Розроблений алгоритм проведення судововетеринарної експертизи з визначення ступеня тяжкості шкоди, заподіяної здоров'ю тварини, здатний позитивно вплинути на ефективність проведення i результативність судово-ветеринарної експертизи, надання обгрунтованого i об'єктивного висновку експерта в категоричній формі.

Перспективи подальших досліджень полягають в обгрунтуванні шкоди здоров'ю, заподіяної підекспертним тваринам, відповідно до характеру різних видів тілесних ушкоджень та розроблених судововетеринарних критеріїв в експертній практиці.

\section{References}

Alleyne, E., \& Parfitt, C. (2019). Adult-Perpetrated Animal Abuse: A Systematic Literature Review. Trauma violence \& abuse, 20(3), 344-357. doi: $10.1177 \% 2 F 1524838017708785$.

Ascione, F. R., Weber, C. V., Thompson, T.M., Heath, J., Maruyama, M., \& Hayashi, K. (2007). Battered pets and domestic violence - Animal abuse reported by women experiencing intimate violence and by nonabused women. Violence against women, 13(4), 354-373. doi: 10.1177\%2F1077801207299201.

Benetato, M.A., Reisman, R., \& McCobb, E. (2011). The veterinarian's role in animal cruelty cases. Javmajournal of the american veterinary medical association, 238(1), 31-34. doi: 10.2460/javma.238.1.31.

Bertuglia, A., Pagliara, E., Manca, F., Pozzolo, P., \& Mannelli, A. (2020). Prognostic Indicators after Musculoskeletal Injuries in Standardbred Racehorses in Italy. Journal of equine veterinary science, 92, 103180. doi: 10.1016/j.jevs.2020.103180.

Bruinderink, G.W.T.A.G., \& Hazebroek, E (1996). Ungulate traffic collisions in Europe. Conservation biology, 10(4). 1059-1067. doi: 10.1046/j.15231739.1996.10041059.x.

Byrne, A. W., O’Keeffe, J., Fogarty, U., Rooney, P., \& Martin, S. W. (2015). Monitoring trap-related injury status during large-scale wildlife management programmes: an adaptive management approach. European journal of wildlife research, 61(3), 445-455. doi: 10.1007/s10344-015-0916-6.

Caudell, J. N. (2013). Review of Wound Ballistic Research and Its Applicability to Wildlife Management. Wildlife society bulletin, 37(4), 824831. doi: $10.1002 / \mathrm{wsb} .311$. 
Conroy, M., O’Neill, D., Boag, A., Church, D., \& Brodbelt, D. (2019). Epidemiology of road traffic accidents in cats attending emergency-care practices in the UK. Journal of small animal practice, 60(3), 146-152. doi: 10.1111/jsap.12941.

Cooper, J. E., \& Cooper, M. E. (1998). Future trends in forensic veterinary medicine. Seminars in avian and exotic pet medicine, 7(4), 210-217. doi: 10.1016/S1055-937X(98)80066-2.

de Siqueira, A., Cuevas, S. E. C., Salvagni, F. A., \& Maiorka, P. C. (2016). Forensic Veterinary Pathology: Sharp Injuries in Animals. Veterinary pathology, 53(5), 979-987. doi: 10.1177/0300985816655850.

Franckenberg, S., Kern, F., Vogt, M., Thali, M. J., \& Flach, P. M. (2015). Fatal gunshot to a fox: The Virtopsy approach in a forensic veterinary case. Journal of forensic radiology and imaging, 3(1), 7275. doi: 10.1016/j.jofri.2014.11.001.

Glenn D. W. (2019). Animal cruelty and bullying: Behavioral markers of delinquency risk or causal antecedents of delinquent behavior? International journal of law and psychiatry, 62, 77-84. doi: 10.1016/j.ijlp.2018.11.008.

Grugan, S. T. (2019). Capturing Cruelty: A content analysis of companion animal cruelty in the news media. Society \& animals, 27(1), 92-108. doi: 10.1163/15685306-12341530.

Heyerhoff, J. C. Z., LeBlanc, S. J., DeVries, T. J., Nash, C. G. R., Gibbons, J., Orsel, K., Barkema, H. W., Solano, L., Rushen, J., \& de Passille, A. M. (2014). Prevalence of and factors associated with hock, knee, and neck injuries on dairy cows in freestall housing in Canada. Journal of dairy science, 97(1), 173-184. doi: $10.3168 /$ jds.2012-6367.

Higdon, J. W., \& Snow, D. (2008). First Record of a Collapsed Dorsal Fin in a White-beaked Dolphin Lagenorhynchus albirostris, with a Gunshot Wound as a Possible Cause. Canadian field-naturalist, 122(3), 262-264. doi: 10.22621/cfn.v122i3.609.

Hoffman, L.C., \& Luhl, J. (2012). Causes of cattle bruising during handling and transport in Namibia. Meat science, 92(2), 115-124. doi: 10.1016/j.meatsci.2012.04.021.

Holovko, I. A. (2010). Kryminalna vidpovidalnist za zhorstoke povodzhennia $\mathrm{z}$ tvarynamy: avtoref. dys.... k.iu.n.: 12.00.08. Kyiv (in Ukrainian).

Instruktsiia pro pryznachennia i provedennia sudovykh ekspertyz (Nakaz Ministerstva yustytsii Ukrainy vid 08.10.1998 r. № 53/5 (u redaktsii nakazu Ministerstva yustytsii Ukrainy vid 26.12.2012 № 1950/5) (in Ukrainian).

Kryminalnyi protsesualnyi kodeks Ukrainy, № 4651-VI (in Ukrainian).

Langley, R. L., Higgins, S. A. \& Herrin, K. B. (2006). Risk factors associated with fatal animal-vehicle collisions in the United States, 1995-2004. Wilderness \& environmental medicine, 17(4), 229-239. doi: 10.1580/06-WEME-OR-001R1.1.

Li, Q., Deng, D., Tao, J., Wu, X., Yi, F., Wang, G., \& Yang, F. (2015). Ultrasonic imaging of gunshot wounds in pig limb. Genetics and molecular research, 14(2), 4291-4302. doi: 10.4238/2015.april.30.1.
McEwen, B. J. (2012). Trends in Domestic Animal Medico-Legal Pathology Cases Submitted to a Veterinary Diagnostic Laboratory 1998-2010. Journal of forensic sciences, 57(5), 1231-1233. doi: $10.1111 / \mathrm{j} .1556-4029.2012 .02123 . x$.

Mills, G. (2013). Proving the crime: how veterinary forensics can help. Veterinary record, 172(18), 465. doi: 10.1136/vr.f2694.

Munoz, A., Saitua, A., Becero, M., Riber, C., Satue, K., de Medina, A. S., Arguelles, D., \& Castejon-Riber, C. (2019). The use of the water treadmill for the rehabilitation of musculoskeletal injuries in the sport horse. Journal of veterinary research, 63(3), 439-445. doi: 10.2478/jvetres-2019-0050.

Padalino, B., Hall, E., Raidal, S., Celi, P., Knight, P., Jeffcott, L., \& Muscatello, G. (2015). Health Problems and Risk Factors Associated with Long Haul Transport of Horses in Australia. Animals, 5(4), 1296-1310. doi: 10.3390/ani5040412.

Panasiuk-Flak, K., Grela, M., Listos, P., Gryzinska, M., Buszewicz, G., Chagowski, W., \& Teresinski, G. (2020). Forensic veterinary evaluation of gunshot wounds to a dog's head based on traditional examination methods and modern imaging techniques, 76(3), 159-164. doi: 10.21521/mw.6357.

Pro sudovu ekspertyzu: Zakon Ukrainy. Vidomosti Verkhovnoi Rady Ukrainy (VVR), 1994, № 28, st. 232 (in Ukrainian).

Proulx, G., Cattet, M., Serfass, T. L., \& Baker, S. E. (2020). Updating the AIHTS Trapping Standards to Improve Animal Welfare and Capture Efficiency and Selectivity. Animals, 10(8), 1262. doi: 10.3390/ani10081262.

Riley, C. B., Noble, B. R., Bridges, J., Hazel, S. J., \& Thompson, K. (2016). Horse Injury during NonCommercial Transport: Findings from ResearcherAssisted Intercept Surveys at Southeastern Australian Equestrian Events. Animals, 6(11), 65. doi: 10.3390/ani6110065.

Rowan, A. N. (1993). Cruelty to animals. Anthrozoos, 6(4), 218-220. doi: 10.2752/089279393787002169.

Tosswill, M., Roskruge, M., Smith, A., \& Christey, G. (2018). Livestock-related injuries in the Midland region of New Zealand. New zealand medical journal, 131(1483), 13-20. URL: https://pubmed.ncbi.nlm.nih. gov/30286061.

Weber, B., Lackner, I., Haffner-Luntzer, M., Palmer, A., Pressmar, J., Scharffetter-Kochanek, K., Knoll, B., Schrezenemeier, H., Relja, B., \& Kalbitz, M. (2017). Modeling trauma in rats: similarities to humans and potential pitfalls to consider. Journal of translational medicine, 17, 305. doi: 10.1186/s12967-019-2052-7.

Yatsenko, I. V., \& Parylovskyi, O. I. (2020). Novitni dosiahnennia v sudovo-veterynarnii ekspertyzi tvaryn, postrazhdalykh vid zhorstokoho povodzhennia. Naukovyi visnyk Lvivskoho natsionalnoho universytetu veterynarnoi medytsyny ta biotekhnolohii im. S. Z. Hzhytskoho. Seriia: Veterynarni nauky, 22(97), 95-105. doi: 10.32718/nvlvet9716 (in Ukrainian).

Yatsenko, I. V., Parylovskyi, O. I., \& Kolomoiets, D. K. (2019). Obhruntuvannia pytan, shcho stavliatsia V 
ukhvali sudu ta postanovi slidchoho pry pryznachenni sudovo-veterynarnoi ekspertyzy trupa tvaryny $\mathrm{Z}$ oznakamy nasylnytskoi smerti vid zhorstokoho povodzhennia. Veterynariia, tekhnolohii tvarynnytstva ta pryrodokorystuvannia: naukovo-praktychnyi zhurnal, 4, 184-197. doi: 10.31890/vttp.2019.04.34.

Yatsenko, I. V., Parylovskyi, O. I., \& Prykhodko, I. (2019). Sudovo-veterynarni oznaky shkody zdoroviu, nebezpechnoi dlia zhyttia tvaryny. Veterynariia, tekhnolohii tvarynnytstva ta pryrodokorystuvannia: naukovo-praktychnyi zhurnal, 5. 239-245. doi: 10.31890/vttp.2020.05.42 (in Ukrainian).

Yatsenko, I. V., Zapara, S. I., Zakhariev, A. V., \& Skrypka, M. V. (2018). Serdiukov Ya. K. Sudovoekspertni vypadky doslidzhennia trupiv tvaryn $\mathrm{Z}$ oznakamy nasylnytskoi smerti vid zhorstokoho povodzhennia. Problemy zooinzhenerii ta veterynarnoi medytsyny: Zbirnyk naukovykh prats Kharkivskoi derzhavnoi zooveterynarnoi akademii, 36(2), 130-138 (in Ukrainian). 